\title{
CYTOKINES AND BRAIN-DERIVED NEUROTROPHIC FACTOR IN CONTEXT OF COGNITIVE IMPAIRMENT IN THE ELDERLY
}

\author{
Yu.Yu. Filippova, M.E. Kholodilina, A.L. Burmistrova \\ Chelyabinsk State University, Chelyabinsk, Russia

\section{ЦИТОКИНЫ И НЕЙРОТРОФИЧЕСКИЙ ФАКТОР МОЗГА В КОНТЕКСТЕ КОГНИТИВНЫХ НАРУШЕНИЙ У ПОЖИЛЫХ ЛЮДЕЙ}

\author{
Ю.Ю. Филиппова, М.Е. Холодилина, А.Л. Бурмистрова \\ ФГБОУ ВО «Челябинский государственный университет», Челябинск
}

\begin{abstract}
The aim is to assess the levels of certain cytokines IL-6, TNF- $\alpha$, IL-1 $\beta$ и IL-10, and BDNF in the blood plasma of the elderly, depending on degree of cognitive impairment. 65 elderly with (vascular dementia) or without cognitive impairment were enrolled in the study. The level of cytokines and BDNF were measured in plasma by ELISA. It was found that, regardless of the degree of cognitive impairment, the condition of systemic chronic low-grade inflammation is characteristic of the elderly. Against this background, plasma levels of BDNF were increased in elderly with vascular dementia, reaching statistical significance compared with healthy individuals. Such changes in the level of BDNF may reflect a compensatory repair mechanism in neurodegeneration or be associated with a defective axonal transport or utilization of BDNF in the central nervous system paralleled by increased serum concentrations.
\end{abstract}

Keywords: cytokines; BDNF; cognitive impairment.

Целью исследования являлось оценить уровни цитокинов: IL-6, TNF- $\alpha$, IL-1 $\beta$ и IL-10, и BDNF в плазме крови пожилых людей с разной степенью когнитивных нарушений. 65 людей пожилого возраста с наличием (сосудистая деменция)/отсутствием когнитивных нарушений были включены в исследование. Уровни цитокинов и BDNF определяли с помощью ИФА. Обнаружено, что не зависимости от степени когнитивных нарушений, для пожилых людей характерно состояние системного хронического низкоградуированного воспаления. На этом фоне у пожилых с сосудистой деменцией были повышены уровни BDNF в плазме крови, достигая статистической значимости по сравнению со здоровыми индивидуумами. Такие изменения уровня BDNF могут отражать механизм компенсаторной репарации повреждений при нейродегенерации, либо быть связаны с дефектами аксонального транспорта или утилизации BDNF в центральной нервной системе с повышением его концентрации в сыворотке.

Ключевые слова: цитокины; BDNF; когнитивные нарушения.

Introduction. It is believed, that pro-inflammatory cytokines are one of the key factors in the development of neurodegenerative processes [2]. Cytokines are key regulatory mediators involved in the host response to immunological challenges, but also play a critical role in the communication between the immune and the central nervous system. For this, their expression in both systems is under a tight regulatory control. However, pathological conditions, including age-related diseases, may lead to an overproduction of pro-inflammatory cytokines that may have a detrimental impact on central nervous system [3]. One of the mechanisms by which inflammation may affect brain function could involve brain-derived neurotrophic factor (BDNF) modulation. In the brain, BDNF is involved in plasticity, neuronal survival, and formation of new synapses, and dendritic branching [5]. The effect of the cytokines on BDNF results from the integration of multiple mechanisms, including the action of pro-inflammatory cytokines on the neurotransmitters glutamate and gamma-aminobutyric acid, and the stimulation of glucocorticoids production $[3,4]$. In many studies, BDNF has been shown to reduce in the brain in cognitive impairment, including Alzheimer's disease and major depression, however, data on the levels of BDNF in the blood plasma are contradictory $[1,2,5]$. The aim was to assess the levels of certain pro- and antiinflammatory cytokines and BDNF in the blood plasma of the elderly, depending on the presence/ absence of cognitive impairment.

Material and methods. 65 elderly people (age $79 \pm 5$ years), living in Chelyabinsk Gerontology Center, were enrolled in the study. All persons underwent cognitive impairment monitoring using a classification of vascular encephalopathy stages proposed by N.N. Yakhno et al. (2005) and was divided into 2 groups: 44 people with mild cognitive impairment - an "active longevity" (AL) group, and 21 persons with severe cognitive impairment manifested mainly by vascular dementia, a "charity" (C) group. The comparison group consisted of randomly selected 25 healthy donors. 
The average age is $39 \pm 4$ years. The level of cytokines: IL-6, TNF- $\alpha$, IL-1 $\beta$ and IL-10 (Vector Best, Novosibirsk) and BDNF (R \& D Systems, USA) were measured in plasma by ELISA. Statistics: to assess the central tendency, the medians and 25-75 percentiles were calculated, to assess the significance of differences between groups, we used Kruskal-Wallis test.

Results and discussion. It has been shown that in the elderly, regardless of the degree of cognitive impairment, systemic levels of IL-6 and IL-1 $\beta$ were significantly increased compared with similar indicators of healthy donors. However, in the group of people with mild cognitive impairment (AL), high levels of pro-inflammatory cytokines were partially compensated for by an increase in IL-10 (significant differences with the donors). Persons with severe cognitive impairment, predominantly manifested by vascular dementia (group C), demonstrated the highest lev- els of IL-6 in circulation with average IL- $1 \beta$ and IL-10 values. Against the background of systemic chronic low-grade inflammation, plasma levels of BDNF were increased in elderly with vascular dementia, reaching statistical significance in comparison with healthy individuals $(20495 \mathrm{pg} / \mathrm{mL}$; $14854 \mathrm{pg} / \mathrm{mL} ; 11998 \mathrm{pg} / \mathrm{mL}$ for groups C: AL and donors, respectively). Our data are consistent with the data of Angelucci F. (2010) on the increase in serum BDNF in cognitive impairment. Such changes in the level of BDNF may reflect a compensatory repair mechanism in neurodegeneration or be associated with a defective axonal transport or utilization of BDNF in the central nervous system paralleled by increased serum concentrations [1].

Conclusion. Other studies are necessary to establish a direct link between peripheral levels of cytokines and BDNF and cognitive impairment in determining these events.

\section{References}

1. Archer T. BDNF integrity in ageing and stress. MOJ Gerontol. Ger. 2017;1(6):155-158.

2. Calabrese F, Rossetti AC, Racagni G, et al. Brain-derived neurotrophic factor: a bridge between inflammation and neuroplasticity. Front. Cell Neurosci. 2014;22:430.

3. Weinstein G, Beiser AS, Choi SH, et al. Serum brain-derived neurotrophic factor and the risk for dementia: the Framingham Heart Study. JAMA Neurol. 2014;71(1):55-61.

4. Angelucci F, Spalletta G, di Iulio F. Alzheimer's diseases and mild cognitive impairment patient are characterized by increased BDNF serum levels. Curr. Alzheimer Res. 2010;7(1):15-20.

5. Galic MA, Riazi K, Pittman QJ. Cytokines and brain excitability. Front. Neuroendocrinol. 2012;33:116-125. 